JWAM

14,1

4

Received 8 February 2021

Revised 20 March 2021

4 May 2021

Accepted 15 May 2021

\section{Using reflective, authentic assessments to embed employability skills in higher education}

\author{
Elizabeth Miller \\ Pearson Business School, Pearson College London, London, UK, and \\ Iro Konstantinou \\ Pearson College London, London, UK
}

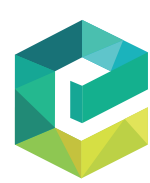

Journal of Work-Applied Management Vol. 14 No. 1, 2022 pp. 4-17 Emerald Publishing Limited 2205-2062

DOI 10.1108/JWAM-02-2021-0014

\begin{abstract}
Purpose - Reflection on performance and progress prepares students for workplace environments where selfmanagement is expected, and yet this is something students are not often required to do formally in higher education (HE). This paper explores this gap in students' ability and seeks to address it through a reconsideration of summative assessment practices which, particularly in light of COVID-19, must align with the needs of graduates and their employers.

Design/methodology/approach - The paper draws from data collected from the summative reflective assessment reports that degree apprentices (DAs) submitted during the final year of their Business Management degree while undertaking a problem-based module. We undertook a document analysis of these reports and used thematic analysis where we systematically looked for repeated themes in students' reflections. Findings - Students problematise the skills needed during COVID-19, and beyond, both in their academic studies and the workplace. Authentic assessment provides opportunities for students to work on skills and projects which are relevant to them. Through reflective accounts of skills they developed, students were able to bridge academic and professional practice and identify areas of convergence. Students engaged with academic theories in a constructive and meaningful way which suggests that authentic reflective accounts as part of assessment have the potential to maintain academic rigour.

Originality/value - Skills development can bring the workplace into HE in a meaningful and systematic way and this article provides guidance for those looking to introduce reflection on skills to other courses. We suggest how this model can be utilised across modules which do not have work-integrated learning in their delivery.

Keywords Authentic assessment, Employability, Higher education, Reflection, Skills development,
\end{abstract} COVID-19, Work-integrated learning

Paper type Research paper

\section{Introduction}

Higher education (HE) must prepare students for changing ways and types of work so that graduates are not only employable but also "safe and effective in whatever roles they take on" (Ajjawi et al., 2018, p. 8). Governments around the world increasingly emphasise that the ways higher education institutions (HEIs) develop the employability of their graduates is a crucial part of the purpose of HE (Rowe and Zegwaard, 2017) and HEIs must look to how they will develop in their students, the skills that graduate employers want. The CBI/Pearson

$\overline{\text { c Elizabeth Miller and Iro Konstantinou. Published in Journal of Work-Applied Management. Published }}$ by Emerald Publishing Limited. This article is published under the Creative Commons Attribution (CC BY 4.0) licence. Anyone may reproduce, distribute, translate and create derivative works of this article (for both commercial and non-commercial purposes), subject to full attribution to the original publication and authors. The full terms of this licence may be seen at http://creativecommons.org/licences/by/4.0/ legalcode

Funding for this research came from a Research England/Office for Students award for Knowledge Exchange as part of funding Pearson College London was awarded for the project "Work Integrated Learning: Sustainable models for student-industry engagement”. 
(2019) Skills Survey found firms had clear views of which skills were critical for the development of their business: leadership and management, work readiness and planning and organisation. However, graduates need to leave $\mathrm{HE}$ not just with certain skills and knowledge, but also the ability to apply this independently and to navigate their careers (Bridgstock, 2009). The literature on employability repeatedly emphasises the importance of students developing skills related to their "self": self-reflection, self-exploration, selfconfidence and self-management all allow students to deploy their knowledge in practice and are expected by employers (Rowe and Zegwaard, 2017). The ability to "self-manage" is thus crucial to graduate success and HEIs must ensure students are prepared for this.

COVID-19's disruption of the world of work has made graduate prospects less certain and so developing employability skills in graduates is even more crucial in preparing them to manage their careers and their work. However, there are many challenges bridging the gap between the workplace and the classroom to develop these skills (Konstantinou and Miller, 2020). This paper explores the ways assessment offers an opportunity to embed employability skills in HE curricula and thus prepare graduates for work. Assessment is crucial "by providing learners with the opportunity to demonstrate acquired skills and knowledge, while determining their professional, vocational and academic achievement" (Ashford-Rowe et al., 2014, p. 205). We argue that authentic assessments, and reflective assessments in particular, help develop self-management skills and help prepare students for the ways they will be evaluated in the workplace.

At our institution, we require students on our Business Management (BM) workintegrated learning (WIL) undergraduate programme to undertake a series of self-managed learning (SML) modules. Originally intended to give students flexibility to explore topics of interest to them and their organisations, our iterative approach to teaching this module, based on student feedback and our reflection as practitioners, has led to us refining this approach. We still give students flexibility to choose an area that is relevant to their job role and their business but we now require them to take a structured problem-solving approach. They must identify an issue or problem in their workplace and work to provide their employer with a solution. Beginning in the first year of their degree (Level 4 of the FHEQ) and repeated with different problems in second year (Level 5) and their third and final year (Level 6). Alongside solving this problem, we teach students how to reflect on their approach to problem-solving and the skills they developed along the way with the aim of helping students not only develop skills but also develop an awareness of these skills and the ability to articulate them. Over a 12 -week period, we support students becoming independent learners by providing 10, twohour long seminars focused on problem-solving skills as a well as reflection. We require students to work with their employers to identify a problem or challenge they would like to address and we also require students to evaluate the solutions they are proposing, ideally including feedback from relevant stakeholders. Students must submit a short proposal at the start of the term to tutors for feedback and we provide students feedback on how they can link their topic with relevant theory. Halfway through the term, students then submit a progress report (as a video) before submitting a final report at the end of the term. Students are thus given multiple points of feedback and are expected to address this feedback.

This paper uses a document analysis of the summative, authentic assessments of a group of Level 6 students undertaking a problem-based learning module to explore reflection as an approach to embedding employability skills in HE. We will explore how students reflected on the skills they developed while undertaking the module and the ways they related this to their future employment prospects. The group of students taking this module were mostly degreeapprentices on a WIL programme; however, at the time they took this module, not all were in work due to COVID-19. Exploring the experiences of the students not in work and comparing them to those in work allows us to consider the ways reflective, authentic assessments might be used to embed employability skills in non-WIL modules and programmes.
Employability skills in higher education 
JWAM
14,1

6

\section{Literature review}

We explore below the ways employability skills and reflection have and can be embedded in degree provision broadly, before looking to assessment as a specific mechanism to embed these crucial skills in students' HE experiences. Authentic and reflective assessment then provides a chance to explore ways work-based assessment can help prepare students for the workplace.

\section{Embedding skills and reflection in degree provision}

Various studies over the years have suggested that explicitly teaching and embedding transferable skills in the curriculum is vital. For example, Walker and Finney (1999) who taught students several skills that can help with research found that students developed a more thoughtful, open-minded and enquiring approach to their personal and professional lives. Tang (2019) found that HEIs in the UK have been rethinking the role of career services, academics and support services, to ensure that employability skills are given prominence in their provision. On a more practical level, the study found that academics in the UK were considering where such skills could be explicitly instructed in the curriculum and cocurriculum. Peterson (2014) also placed urgency on courses which require students to apply critical thinking skills and prepare them to tackle complex problems which can be found in the workplace. In work-based programmes, it is more common for this bridge between theory, practice and skills to be embedded in curricula. Yap (2012) for example, describes a course which was specifically designed to give students the opportunity to complete a curriculum-aligned module which was embedded in industry, alongside professionals. Such courses both develop skills needed at the workplace and provide the links between theory and practice.

Ways that this can be done more broadly include building reflection and metacognition in the curriculum and encourage students to actively think of their goals and capabilities. Dewey (1923, cited in Cendon, 2016) first described how bridging theory and practice can be the most effective way for learning by noting that a small amount of experience can be a lot more powerful than a lot of theory. In the modern institutions, this can take the shape of linking the academic world to the professional world and enabling the convergence of theory and practice whereby students transfer their knowledge across the two settings (Cendon, 2016).

Our paper argues that reflection is integral in students developing those necessary skills and the ability to bridge theory and practice. As Ryan (2013) argues, students should be taught explicitly how to reflect as this enables them to produce thoughtful evidence about new ways of thinking and doing. van Beveren et al. (2018) also argue for the explicit articulation for the value of reflection. A similar argument is made by Veine et al. (2020) who argue that reflection can help students learn how to tackle interdisciplinary and global challenges. However, McCarthy (2011) suggests there is a gap both in HE and practice and on how reflection can be used as the basis for lifelong learning and how it is sometimes used in a tokenistic way. Our paper hopes to fill this gap and show the practical application for reflection, advancing Schön's (1983) suggestions about reflection on and in action and on reflecting on one's own outcomes.

The prominence of focusing on skills stems from the fact that employers increasingly consider transferable skills as more important than a degree when recruiting graduates (Succi and Canovi, 2020). It is also important to note that recent careers are dynamic and people need to self-manage their transitions between jobs and areas of work and manage change continuously (Römgens et al., 2020). Therefore, for HEIs who strive to instil employability skills in their students, it is worth remembering that employability is a multidimensional concept which should encompass elements which often to be overlooked such as 
achieving work-life balance and lifelong learning (Römgens et al., 2020). This urgency to rethink what skills graduates will need as they enter the workplace post-COVID-19 has been noted by industry experts. For example, a report by McKinsey argues that digital, cognitive, social, emotional, and adaptability and resilience skill sets will be needed by future employees (Feld et al., 2020). Similarly, the World Economic Forum notes that educational institutions need to build power learners and adaptable, resourceful and entrepreneurial earners (Belanchew and Surkin, 2020).

\section{Does summative assessment in education prepare students for the workplace?}

Just as there is discussion (see above) about the need for HE curricula to prepare students for work, there are similar conversations among scholars about the role assessment plays in this process. Despite criticisms of assessment in $\mathrm{HE}$ as ill-preparing students for work (Ajjawi et al., 2018) and acknowledgment of the need for more assessment for, rather than of, learning, criteria and competency-based assessment remains common in post-secondary education (Torrance, 2007). Torrance argues that these approaches "probably help to produce students who are more dependent on their tutors and assessors rather than less dependent" (Torrance, 2007, p. 282). Confidence and self-efficacy are important to employers and to students, who will need to manage their own careers after they graduate (Bridgstock, 2009). However, research has shown that employers believe graduates to be lacking important skills and moreover, when employer ratings of the graduates' skills were compared with the graduates' self-assessment, graduates overestimated their skills and competence when compared with employers' perceptions (Lisá et al., 2019). It seems there are still gaps, therefore, in HEIs attempts to effectively create curricula and assessment that embed employability skills.

Traditional assessment in education tends to require learner to either recognise or recall knowledge (Wiggins, 1990). This may be useful for assessing the acquisition of disciplinespecific knowledge but does not mirror the nature of how knowledge is assessed in most workplaces, and a crucial part of $\mathrm{HE}$ is preparing students for the workplace (Rowe and Zegwaard, 2017). Employers have indicated in research that they valued most highly assessments that occurred not in education settings, but in the "real-world" (Cooper et al., 2010) and skills particularly valued were the ability to recognise areas for development, respond to feedback and improve their work (Ajjawi et al., 2018). In this way, formative assessment is more akin to workplace assessment. Nonetheless, summative assessment is a crucial part of being able to offer a qualification or award (Cooper et al., 2010). As professional bodies have moved to link $\mathrm{HE}$ and professional values and practice more closely (Gonczi, 1994), there have been accompanying calls for this summative assessment to be more authentic (Boud, 1999).

The authenticity of authentic assessment, which is primarily summative, is based on the learner being able to complete tasks in meaningful contexts leading to the acquisition of knowledge and should not be confused with "authentic assessment for learning" which is typically formative (Swaffield, 2011). Authentic assessments more closely replicate the challenges found in the "real world" and "present the student the student with the full array of tasks that mirror the priorities and challenges found in the best instructional activities" (Wiggins, 1990, p. 1). This approach to assessment has also been shown (Fook and Sidhu, 2010) as appealing to students who see this as a chance to develop knowledge and skills valued, and indeed required, by employers. In WIL contexts, assessment should provide "evidence that the student is a reflective practitioner capable of self-development, understands the world of work, knows the rules of the profession or workplace setting, and acts in a professional way" (Cooper et al., 2010). We argue that this conception of WIL's authentic assessments would also add value to students not currently in work.

Employability skills in higher education 
JWAM

14,1

8
Authentic, reflective assessment and employability

One approach to authentic assessment that prepares students for the world of work is problem-based learning. Students are the centre of this approach to learning. They must solve ill-structured problems with tutors acting as guides or facilitators, but this approach emerged in medical education and while it is practiced in other disciplines, much research is still based in this field (Walker and Leary, 2009). We argue that problem-based learning will be most effective when there is a workplace setting, as the workplace "has the potential to provide the kinds of challenges that provoke and enhance attainment of formal operational capabilities" (Cooper et al., 2010, p. 64).

While criticisms have been made of authentic work-based assessment "where the doing of the task does not have 'real' consequences" (Cumming and Maxwell, 1999, p. 12), for students on WIL programmes this presents less of a risk. For the mostly working students on the programme discussed in this paper, the alignment between work and assessment that is critical to authentic assessment (Herrington and Herrington, 2006) exists because the students design the assessment task themselves based on a genuine problem confronting them in the workplace. It thus appears that a key gap is creating opportunities for "real" assessments for students who are not working. Reflection is one way to bridge this gap as this is a form of self-assessment valued and practiced in many workplaces (Schön, 1983).

Critical reflection has long been a skill important in many professions, including those in business (Schön, 1983). Students must learn to reflect and self-evaluate to understand feedback, to understand if their work is of an acceptable standard, and to know "when they need to ask for assistance from others or undertake further learning" (Ajjawi et al., 2018). We adopt the definition of Béres and Fook who argue that "critical reflection involves learning from and making deeper meaning of experience through a process of unsettling and examining deeply hidden assumptions in order to create better guidelines for action and so improve professional practice" (2019, p. 2). Creating authentic and work-based assessments relying on critical reflection on the part of the students therefore allows students to develop an array of professional skills and, perhaps crucially, begin to understand how they can improve their professional practice. Reflection, as well as being a key skill employers value, also allows students to explore and develop other key employability skills. We propose below that for students not in work, the consequences of a skills-development, reflective approach is one way of meeting the criticism outlined above because developing these skills and doing the tasks required to reflect on their skills development, does indeed have "real" outcomes and consequences for students.

\section{Methodology}

The site of research is a private HEI in central London where the largest undergraduate programme is a BM degree. The problem-based module at the centre of this study is mostly studied by our degree apprentices (DAs). DAs on the BM programme must, as part of their degree, complete three self-managed learning modules - one at each level of study. These modules adopt a WIL pedagogical approach so students must complete projects which are based on their workplace. One of the main features of this pedagogy is that students bring what they have learnt in the workplace into the classroom, and take classroom learning into the workplace (Ram et al., 2009). This integration and exchange of skills and knowledge also transfers into assessment. Therefore, our data collection was based on data collected through coursework submitted by students on self-managed learning (SML) modules at Level 6, their final year of studies. The module carries 30 credits and has three components: a proposal, a progress video and a 6,000-word report. For the last part of their assessment, the brief outlines that students need to identify a business-related problem relevant to their work context and identify solutions. They then complete a process of evaluation of these solutions and conclude 
with recommendations. The process of identifying the problem to recommending solutions moves beyond only being able to write an academic report. It requires students to liaise with business stakeholders, engage with problem-solving frameworks and provide and receive feedback from peers at the workplace and the classroom, to name just a few of the elements which are part of the module outcomes. Overall, we believe that being able to solve a real business problem equips students with employability skills which are fundamental to their roles as DAs. To be able to successfully integrate skills and knowledge and complete the assignment as outlined above, students need to showcase several such skills. We outline some of these skills for students to ensure they have a point of reference; however, they are encouraged to move beyond those they wish to and incorporate a wider range of employability skills as relevant to their employer and context. We do not assess how well students develop these skills, but their ability to self-reflect and constructively identify areas of progress and improvement. We find that usually students look at the literature and relevant theories to find definitions of such skills, they provide concrete examples of how they believe they have developed the skills, and incorporate reflective models for reflection, such as Gibb's reflective cycle.

To understand how assessment can provide evidence for learning and opportunities for engagement with relevant academic theories, we analysed student reports focusing on the parts where they self-reflect on their development of skills over the course of the term. In total, we looked at ten student reports from a cohort of 60 students. We selected five students who had a first and five students who had a $2: 1$. The selection of the ten papers was done by taking the top five from the firsts and 2:1 papers based on their alphabetical order. We wanted to showcase examples of students who have managed to self-reflect in a way which shows best practice of such assignments which informed our decision to choose students with high grades. We tend to see that students with higher grades in the overall assessment tend to perform strongly in the skills development reflective part; although, this has not been studied empirically and can form the basis of another study. This is not to say that students with lower grades did not provide examples of good self-reflection. However, as we wanted to showcase best practice and draw recommendations for how skills development can be embedded into assessment, we chose students who had done this in a way which could show how this can be done successfully. We draw from the theories around self-efficacy (Bandura, 1986) which suggest that students can develop notions of confidence if they can see good examples of performance from their peers. We hope that practitioners who wish to adopt a similar approach to assessment can be convinced from what is possible. With regards to reviewing a small sample, it is worth pointing out that the self-reflective part of the assessment is between 1,000-1,500 words; therefore, we believed that ten reports would provide sufficient evidence which would form the basis for this paper. We also ensured that our chosen sample had a mixture of students who were in employment and those who were furloughed so we could draw comparisons between the two.

Even though it would strengthen the paper to collect data from other sources, since the data involved assessment it would be difficult to collect data from students as the unbalanced relationship between lecturers/researchers and students might compromise the reliability of data. Documentary analysis was used in this study as a data collection method which allows researchers to view progress over time through the reflections of those completing the documents (Bowen, 2009). We have taken a similar approach by choosing students at their final year. For the analysis of data, we used thematic analysis where we systematically examined the data looked for repeated themes. We define themes as "reflecting a pattern of shared meaning, organized around a core concept or idea, a central organizing concept" (Braun et al., 2018).

While document analysis has the advantage many other qualitative methods share in research into assessment as it "yields findings that are rooted in the particular context of the
Employability skills in higher education 
JWAM

14,1

study" (Chism and Banta, 2007, p. 26), it entails ethical considerations. In our case, these considerations arise because of the relationship between the authors and the students, whose work we were assessing. This project complies with the ethics approval process of our institution and we explained to students at the start of the module that their assessments would be used for research into the development of employability skills. All students were sent a written email outlining our research and were informed that we would be using parts of their reports confidentially as our data. Students were given the chance to opt-out of having their work used this way and we assured them that their current and future marks would not be affected if they opted out. Students were told that they could reply to the email at any time during the term and withdraw from the study without having to give explanation for their withdrawal. We acknowledge that as their tutors and assessors, the students may have felt they should participate to please us, however, many of the students had a genuine interest in our project. We had completed research with these students in the past and shared our findings and conclusions with them and many of them went on to use this in the module being considered here as it related to their ability to reflect and develop skills. All identifying information has been removed from the data presented below.

\section{Data analysis}

\section{Authentic assessment}

Students are more likely to engage with assessment when they see the value of it and how it might link to other modules or their goals outside education. For example, one student saw the value of reflecting on her leadership style as part of a task she had to complete at work. She said:

My workplace manager recently delegated a small campaign to me to manage and gather reports on; this campaign involves leading my peers in my team as well as senior [teammates] and is reported directly into our senior leadership team. I have therefore had the opportunity recently to place academic theories I have been educated on during my time at [HEI] into my role at [company] directly.

Ensuring that students can identify these links is important as is equipping them with the language to talk about the importance of such links. The example above evidences how students can see the value of what they do for their academic assessments in terms of how it can translate into workplace practice.

Student engagement with study, their self-confident and their sense of "belongingness" are critical to student success (Yorke, 2016) and authentic assessment provides an important opportunity for students to feel engaged with their learning. Students' engagement with assessment was captured when we saw that they could make a direct link to how the coursework might help with their future employability skills, especially since some students found themselves on furlough while they were completing their assignments.

One student decided to use this time to develop wider employability skills using the framework developed by Dacre Pool and Sewell (2007). Through the audit she completed at the beginning of the term and her subsequent self-reflection, she realised that self-confidence and self-esteem were areas she needed to focus on. She used the term and this module to choose her own focus for her assessment to work on these areas. Losing a job, albeit temporarily, meant that some students had to deal with the stress caused by this. Having the space to reflect on how they can improve their employability skills as part of their coursework, offered them the opportunity to focus their academic efforts on something which was important for them personally at a time when they had to deal with the uncertainty on their employment. Giving students the opportunity to reflect and complete their assessment on their progress can be a powerful tool to engage their interest in the topic. Having the ability to choose one's topic can enhance self-efficacy and motivation (Bandura, 1986). 
Another student also explained how assessment helped develop necessary skills, especially as he was also on furlough, and therefore indicated what he saw as the benefits of this type of assessment. He said:

Going through a redundancy process has meant effective communication on my behalf has been crucial, given the process has been a virtual one. In the classroom, teamwork and communication has become an even more crucial skill when studying remotely, to manage not only the change of working environment but also support other students.

A theoretical consideration of assessment in education is focused on "the need for learning and assessment of learning to be contextualised and meaningful for students" (Cumming and Maxwell, 1999, p. 177). This consideration is particularly important in WIL programmes where the students' learning, and assessment, is contextualised to their workplace. This student, despite going through the redundancy process, perceived his assessment as meaningful. He also reflected that despite the difficulties in his workplace, it was important for him to attend classes to help maintain his teamwork and communication skills, which was a focus of his assessment. This is evidence of his ability to participate in teamwork despite the challenging circumstances and also of the ways authentic assessment can facilitate skills development in ways that are crucial to students' employability (AshfordRowe et al., 2014).

\section{When practice meets theory}

A worry which academics might have is that a reflective approach to assessment might mean that students will not engage substantially with academic theory and might perceive such an assignment as lacking in academic rigour. However, our data suggest that when students are encouraged to engage in guided reflection, they are very adept at bridging theory with practice. For example, a student wanted to understand better their level of competence in certain skills. For this they used Burch's model of the Conscious Competence Ladder. Another student adopted Boud's model of Reflective Learning. Students are encouraged to use these models to reflect both on what happens in the classroom but also what happens at the workplace, and it is interesting to consider some examples of how this happens. For example, using the Boud model one student wrote:

Whilst I appreciate the need to self-reflect [. . . ] in this report I have taken a less structured approach and focused more on intuition and emotional reflection. The ability to reflect emotionally is key to my role at work, which requires a high degree of emotional intelligence and I hope that by understanding my own feelings in a situation, it can help [me] understand how others feel.

The student used Boud's reflective model to reflect out loud to a colleague as a process of being accountable to others. The colleague provided feedback on how impressive the journey she witnessed had been and how she was considering engaging in self-reflection herself. We know that reflection is part of professional identity and the process can form part of appraisals, promotions and pay rises. The above example shows how academic work can form the basis of such reflection and provide students with the necessary tools to engage in reflection which can lead to academic progress (Lew and Scmidt, 2011) and contribute towards their professional practice (Boud, 1999).

Another area which can benefit students both at the workplace and the classroom is the ability to identify areas for progress and to set goals. This is often required from them in both settings but rarely are they given the necessary language or frameworks to do so in a way which can lead to measurable outputs. Since setting goals is part of the assessment in our modules, students familiarise themselves with the literature on self-regulation, self-efficacy and goal setting. For example, a student used the work of Barry Zimmerman on selfregulation to frame how she discussed her goals and how they would be achieved. The same
Employability skills in higher education 
JWAM

14,1

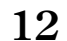

student used a reflective diary to track her progress based on Gibb's reflective cycle. Figure 1 shows an example of how the diary was used.

The student felt she benefited from the process of tracking her progress reflecting on how she felt during various situations, which helped her manage stressful situations. Our data shows how able and eager students are to utilise academic theory which can be used to measure their academic progress but also inform their professional practice. Even though we suggest some academic theories and reflective models students can use, they were encouraged to read widely and identify further theories which could be used in their contexts. Having the ability to choose their own topics, made this process easier and enabled students to engage with academic work spanning different disciplines. This process not only strengthened their academic output but also made them stand out at the workplace. The process also reflects our pedagogical approach to authentic, reflective, work-based assessment. On Bosco and Ferns' (2014) Authentic Assessment Framework, our approach would rate as being "highly authentic" in both an educational and workplace setting. Students are actively engaged with an authentic audience (their employer) and the workplace, intellectual engagement is required in their assessment, as learners, they must reflect on their performance, and industry contributes to assessment because students must work with their managers to set the parameters of their project. Where the students were furloughed or not in work, their reflection became the crucial link between their assessment and their future work and thus made this assessment authentic even if they were not currently in work. Pleasingly, there were no notable differences between the quality of reflective work produced by students in work compared with those who currently were not in work, perhaps because even though these students were not in work, the assessment was still authentic to them.

For students on DA programmes, the expectation that WIL pedagogies will be a key part of their teaching is clear and these WIL practices are part of their programme design. However, this research points to the potential for WIL pedagogies to enhance the programmes of non-apprentice learners too, and WIL could "provide a valuable reference point for quality assuring this provision" (Lillis and Bravenboer, 2020, p. 727). The ability of students on furlough to see their professional skills developing in the same way that their working peers did is encouraging. The act of solving "real-world" problems while reflecting on the skills deployed and developed in this process makes the learning authentic to students in a variety of contexts. This problem-solving approach grounded in WIL could therefore be applied to a variety of non-WIL programmes to help develop the employability of nonworking students.

\section{Skills beyond COVID-19}

Students were completing these assignments when COVID-19 had been a source of disruption for several months. Many of the topics students chose focused on how their respective companies could deal with the impact of COVID-19 both in terms of the working

Figure 1. Reflective diary

\begin{tabular}{|l|l|l|l|l|l|}
\hline Week & Description & Feelings & Evaluation & Conclusion & Action plan \\
\hline 6 & $\begin{array}{l}\text { What } \\
\text { happened? }\end{array}$ & $\begin{array}{l}\text { How did I } \\
\text { feel? }\end{array}$ & $\begin{array}{l}\text { What was } \\
\text { good/bad? }\end{array}$ & $\begin{array}{l}\text { What else } \\
\text { could I do? }\end{array}$ & $\begin{array}{l}\text { How do I } \\
\text { improve? }\end{array}$ \\
\cline { 2 - 6 } $30 / 10 / 20$ & $\begin{array}{l}\text { Submitted } \\
\text { video review } \\
\text { and moved to } \\
\text { a new house in } \\
\text { the same } \\
\text { weekend }\end{array}$ & $\begin{array}{l}\text { Stressed, I } \\
\text { ended up } \\
\text { finishing my } \\
\text { video during } \\
\text { the weekend } \\
\text { in which I } \\
\text { moved to a } \\
\text { new house }\end{array}$ & $\begin{array}{l}\text { I feel my time } \\
\text { management } \\
\text { could have } \\
\text { been better, I } \\
\text { didn't want to } \\
\text { submit my } \\
\text { presentation } \\
\text { so late in the } \\
\text { day }\end{array}$ & $\begin{array}{l}\text { Ensure that I } \\
\text { stay on track } \\
\text { with the full } \\
\text { report to } \\
\text { avoid having } \\
\text { more stressful } \\
\text { times later in } \\
\text { the term }\end{array}$ & $\begin{array}{l}\text { Factor time } \\
\text { into my weekly } \\
\text { plan when I } \\
\text { know I will be } \\
\text { unable to } \\
\text { make progress }\end{array}$ \\
\end{tabular}


conditions of their employees and in engaging with clients. As they were looking to identify solutions to deal with the consequences of unprecedented circumstances, students reflected on the need to show creative thinking and innovation. As one student put it:

Adaptability is important to embrace change and switching mentality quickly when unprecedented situations arise

The student's project looked at how the organisation she works for could quickly move all of their courses online and this required the skills she mentioned to be used in a real-life setting. Evidently COVID-19 pushed people and organisations to think creatively and do things differently and the assessment enabled the students to reflect on how this process felt and operated for them. In their reflective pieces they acknowledged the importance of having these skills, particularly innovation and creativity, and how they would need to develop them even further for a post-pandemic world where things will not return to normal immediately. This resonates with the reports published by Belanchew and Surkin (2020) who point to such skills as instrumental in the future workplace.

Another student reflected on the fact that COVID-19 has forced many people to become more self-aware since times of uncertainty make people reflect more on their strengths and weaknesses. She commented that the fact she had to reflect on her own development of skills, in a guided way, has enabled her to alleviate some of the stresses which colleagues were facing. For example, looking at what it takes to solve problems and analyse the theory around them, ensured that she was able to transfer some of these learnings to the workplace. She believed that building self-awareness would be something that more and more employers will be requiring in the future as it allows people to deal with crises more successfully. Reflection on one's progress and productive reflection are not new terms. Boud et al. (2005) in their edited book include several chapters which trace the need for productive reflection in the workplace and how this can translate in the classroom. We also argue that with the sudden changes brought by COVID-19 and the need to adapt to change has stressed the relevance of such a process and made it a necessity for many professionals. COVID-19 also forced many to rethink how they interact with their colleagues and how their communication style online might need to be adapted for a virtual working space. One of the students, who focused on how to improve her leadership style, reflects:

At the start of the SML, I identified that as a project manager of a virtual team, I needed to improve my leadership skills and monitoring of team behaviour in order to intervene in the correct way. [ . ...] For example, I wanted to improve my conflict management strategies for virtual teams, so I researched conflict resolution and used a Harvard Business Review article by Keith Ferrazzi (2012) to guide my conflict resolution strategy. As a result, I ran weekly retrospectives using an online collaboration tool (Mural) to elicit honest feedback from team members and resolve issues as a team.

The student went on to reflect on how they felt more confident in their leadership skills in an online space and provided examples of feedback she received from colleagues which expressed their appreciation for the support they received and the adaptations that were made for online team interactions. Overall, it was interesting to see how some of these learnings encouraged the student to not only reflect and make changes based on the change in circumstances but also find relevant sources to do so which would provide the necessary basis for effective change. A lot of the examples provide by students showed how they sought to work on their communication skills based on the move to online spaces, commenting that some of these practices would stay with them beyond the pandemic.

\section{Conclusions and recommendations}

While we acknowledge that our sample was small and focused on students who performed well academically, we have shown that authentic assessment does not mean compromising

Employability skills in higher education 
JWAM

14,1

academic quality. Indeed, students were able to apply theory to practice in sophisticated ways. That students were consciously developing as reflective practitioners, while also developing subject-specific skills and knowledge, will put these students in a stronger position in the changing world of work. By instilling in students a sense of agency and confidence about their employability, this project has helped equip them to deal with change, notably the ongoing changes in response to the pandemic.

There is a gap between skills developed during $\mathrm{HE}$ and those required by the workplace and we have outlined above one of the ways employability can be embedded in summative assessments to help address this gap. While some (Byrne, 2020) argue that some interventions to improve employability in $\mathrm{HE}$ students are possible though "they are also to a large extent at the mercy of inequalities in society" (1), we argue that programme and module designers can take steps to improve the employability of students. Embedding employability in HE assessments will help prepare students for the changing world of work particularly where this assessment is authentic. Blending reflection, authentic, problembased assessment and explicit skills development is a useful way of developing students' employability skills. Through this type of assessment, students develop not only specific employability skills, but crucially, they also develop important self-management skills and are able to critically engage with wider issues which will help them bring broader employability skills to their work. Students can see the relevance of this approach to their future employment prospects and saw the value of this approach, particularly in light of the challenges COVID will present to many graduates. Evidently, many students struggled during COVID-19 and the wider implications of the disruption to teaching and learning may still impact us for years to come (Pokhrel and Chettri, 2021). Getting students to reflect on these experiences and outline areas of development and future learnings can be an area which HE practitioners choose to embed in future assessments. Even though this is easier in a business context, as students grapple with the impact of COVID-19 on businesses and organisations, we believe that societal, economic, health political, among others, are areas which can adopt a similar approach, without the requirement of a WIL teaching provision. By designing self-managed modules, similar to the ones we describe here, students will get the opportunity to pick a problem which is relevant to their discipline and research solutions through the process we outlined here.

Our sample consisted mainly of DAs; however, there are implications for students who are in mainstream degrees. For students not currently in work, this type of assessment still provided them with the chance to develop employability skills in ways that were "real" and meaningful to them. As shown from the examples from students who were on furlough, nonworking students were still able to engage with a problem-based approach to their assessment and engaged in meaningful reflection. There is an emphasis in HE to secure internships or engage with industry on various levels. Evidence shows that not many students engage with events organised by career offices; however, with graduate outcomes being important for league tables it is important to find embedded ways to increase students' awareness of skills they can develop during their degree (Bradley et al., 2021). We argue that creating assessments which require students to think about what skills they might need to complete reports/coursework can embed transferable skills in the degree provision regardless of their employment status.

The students who were not in work while undertaking this module, whether due to redundancy or furlough, were able to engage with it as effectively as students who were DAs. We thus argue that this approach can be expanded to include students who are not in full/ part-time work by explicitly requiring students to reflect on, develop and think about future management of themselves and their professional identities or through problems facing society more widely. Moreover, this approach could be used on other courses and in other disciplines as the challenges facing graduates are widespread and span different disciplines. 
There is a body of work which looks at self-managed/directed learning which primarily investigates the uses of educational technology and IT. We hope that our paper has shown ways whereby self-managed modules can be adopted more widely. There is scope to research further how our findings can be replicated in mainstream degrees and beyond business schools. We encourage those who design modules and programmes to adopt a problem-based approach to assessment which requires students to not only solve a problem but also engage with and reflect on the transferable skills they can develop through this process. The impact of COVID-19 on businesses, societies and individuals can provide a fertile ground for such investigations.

\section{References}

Ajjawi, R., Tai, J., Dawson, P. and Boud, D. (2018), "Conceptualising evaluative judgement for sustainable assessment in higher education", Developing Evaluative Judgement in Higher Education: Assessment for Knowing and Producing Quality Work, Routledge, Abingdon, pp. 7-17.

Ashford-Rowe, K., Herrington, J. and Brown, C. (2014), "Establishing the critical elements that determine authentic assessment", Assessment and Evaluation in Higher Education, Vol. 39 No. 2, pp. 205-222.

Bandura, A. (1986), Social Foundations of Thought and Action: A Social Cognitive Theory, PrenticeHall, Englewood Cliffs, NJ.

Belanchew, T. and Surkin, R. (2020), "This is the new skills gap for young people in the age of COVID19", World Economic Forum, available at: https://www.weforum.org/agenda/2020/10/youthemployment-skills-gap-covid-19/ (accessed 5 February 2021).

Bosco, A.M. and Ferns, S. (2014), "Embedding of authentic assessment in work-integrated learning curriculum", Asia-Pacific Journal of Cooperative Education, Vol. 15 No. 4, pp. 281-290.

Boud, D. (1999), "Avoiding the traps: seeking good practice in the use of self-assessment and reflection in professional courses", Social Work Education, Vol. 18 No. 2, pp. 121-132.

Boud, D., Cressey, P. and Docherty, P. (2005), Productive Reflection at Work: Learning for Changing Organisations, Routledge, Oxon.

Bowen, G. (2009), "Document analysis as a qualitative research method", Qualitative Research Journal, Vol. 9 No. 2, pp. 27-40.

Bradley, A., Quigley, M. and Bailey, K. (2021), "How well are students engaging with the careers services at university?”, Studies in Higher Education, Vol. 46 No. 4, pp. 663-676, doi: 10.1080/ 03075079.2019.1647416.

Braun, V., Clarke, V., Hayfield, N. and Terry, G. (2018), "Thematic analysis”, in Liamputtong, P. (Ed.), Handbook of Research Methods in Health Social Sciences, Springer, Singapore, doi: 10.1007/978981-10-2779-6_103-1.

Bridgstock, R. (2009), “The graduate attributes we've overlooked: enhancing graduate employability through career management skills", Higher Education Research and Development, Vol. 28 No. 1, pp. 31-44, doi: 10.1080/07294360802444347.

Byrne (2020), "What determines perceived graduate employability? Exploring the effects of personal characteristics, academic achievements and graduate skills in a survey experiment”, Studies in Higher Education, (2020), pp. 1-18, doi: 10.1080/03075079.2020.1735329.

Béres, L. and Fook, J. (Eds) (2019), Learning Critical Reflection: Experiences of the Transformative Learning Process, Routledge, Abingdon.

CBI, \& Pearson (2019), Education and Learning for the Modern World: CBI/Pearson Education and Skills Survey Report 2019, available at: https://www.cbi.org.uk/media/3841/12546_tess_2019.pdf (accessed 6 February 2021). 
JWAM

14,1

Cendon, E. (2016), "Bridging theory and practice: reflective learning in Higher Education", Handbook of Research on Quality Assurance and Value Management in Higher Education, IGI Global. doi: 10.4018/978-1-5225-0024-7.ch012.

Chism, N.V.N. and Banta, T.W. (2007), "Enhancing institutional assessment efforts through qualitative methods", New Directions for Institutional Research, Vol. 2007 No. 136, pp. 15-28.

Cooper, L., Orrell, J. and Bowden, M. (2010), Work Integrated Learning: A Guide to Effective Practice, Routledge, Abingdon.

Cumming, J. and Graham, M. (1999), "Contextualising authentic assessment", Assessment in Education: Principles, Policy and Practice, Vol. 6 No. 2, pp. 177-194, doi: 10.1080/09695949992865.

Dacre Pool, L. and Sewell, P. (2007), "The key to employability: developing a practical model of graduate employability", Education and Training, Vol. 49 No. 4, pp. 277-289.

Feld, A., Riech, A., Störk, K. and Durth, S. (2020), “Thriving after COVID-19: what skills do employees need? McKinsey Accelerate", available at: https:/www.mckinsey.com/business-functions/ mckinsey-accelerate/our-insights/accelerate-blog/thriving-after-covid-19-what-skills-doemployees-need (accessed 5 February 2021).

Ferrazzi, K. (2012), "How to build trust in a virtual workplace", Harvard Business Review, available at: https://hbr.org/2012/10/how-to-build-trust-in-virtual (accessed 20 July 2021).

Fook, C.Y. and Sidhu, G.K. (2010), "Authentic assessment and pedagogical strategies in higher education”, Journal of Social Sciences, Vol. 6 No. 2, pp. 153-161.

Gonczi, A. (1994), "Competency based assessment in the professions in Australia", Assessment in Education, Vol. 1 No. 1, pp. 27-44.

Herrington, J. and Herrington, A. (2006), "Authentic conditions for authentic assessment: aligning task and assessment", Critical Visions, Proceedings of the 29th HERDSA Annual Conference, Western Australia, 10-12 July 2006, pp. 146-151.

Konstantinou, I. and Miller, E. (2020), "Investigating work-integrated learning and its relevance to skills development in degree apprenticeships", Higher Education, Skills and Work-Based Learning, Vol. 10 No. 5, pp. 767-781, doi: 10.1108/HESWBL-05-2020-0112.

Lew, M. and Schmidt, H. (2011), "Self-reflection and academic performance: is there a relationship?", Advances in Health Science Education, Vol. 16, pp. 529-545.

Lillis, F. and Bravenboer, D.W. (2020), "The best practice in work-integrated pedagogy for degree apprenticeships in a post-viral future", Higher Education, Skills and Work-Based Learning, Vol. 10 No. 5, pp. 727-739, doi: 10.1108/HESWBL-04-2020-0071.

Lisá, E., Hennelová, K. and Newman, D. (2019), “Comparison between employers' and students' expectations in respect of employability skills of university graduates", International Journal of Work-Integrated Learning, Vol. 20 No. 1, pp. 71-82.

McCarthy, J. (2011), "Reflective writing, higher education and professional practice", Journal for Education in the Built Environment, Vol. 6 No. 1, pp. 29-43, doi: 10.11120/jebe.2011.06010029.

Peterson, E.A. (2014), "Business Law 360 Degrees: bridging the gap between theory and practice", Journal of Management and Sustainability, Vol. 4 No. 3, doi: 10.5539/jms.v4n3p102.

Pokhrel, S. and Chhetri, R. (2021), "A literature review on impact of COVID-19 pandemic on teaching and learning", Higher Education for the Future, Vol. 8 No. 1, pp. 133-141, doi: 10.1177/ 2347631120983481.

Ram, S., Coll, R., Eames, C., Paku, L., Lay, M., Ayling, D., Hodges, D., Bhat, R., Fleming, J., Ferkins, L., Wiersma, C. and Martin, A. (2009), An Exploration of the Pedagogies Employed to Integrate Knowledge in Work-Integrated Learning in New Zealand Higher Education Institutions, Crown, Wellington.

Römgens, I., Scoupe, R. and Beausaert, S. (2020), "Unraveling the concept of employability, bringing together research on employability in higher education and the workplace", Studies in Higher Education, Vol. 45 No. 12, pp. 2588-2603, doi: 10.1080/03075079.2019.1623770. 
Rowe, A.D. and Zegwaard, K.E. (2017), "Developing graduate employability skills and attributes: curriculum enhancement through work-integrated learning", Asia-Pacific Journal of Cooperative Education, Vol. 18 No. 2, pp. 87-99.

Ryan, M. (2013), "The pedagogical balancing act: teaching reflection in higher education", Teaching in Higher Education, Vol. 18 No. 2, pp. 144-155, doi: 10.1080/13562517.2012.694104.

Schön, D.A. (1983), The Reflective Practitioner: How Professionals Think in Action, Routledge, Abingdon.

Succi, C. and Canovi, M. (2020), "Soft skills to enhance graduate employability: comparing students and employers' perceptions", Studies in Higher Education, Vol. 45 No. 9, pp. 1834-1847, doi: 10. 1080/03075079.2019.1585420.

Swaffield, S. (2011), "Getting to the heart of authentic assessment for learning, assessment in education: principles", Policy and Practice, Vol. 18 No. 4, pp. 433-449, doi: 10.1080/0969594X. 2011.582838 .

Tang, K.N. (2019), "Beyond employability: embedding soft skills in Higher Education”, The Turkish Online Journal of Educational Technology, Vol. 18 No. 2, pp. 1-9.

Torrance (2007), "Assessment as learning? How the use of explicit learning objectives, assessment criteria and feedback in post-secondary education and training can come to dominate learning", Assessment in Education: Principles, Policy and Practice, Vol. 14 No. 3, pp. 281-294, doi: 10.1080/ 09695940701591867.

Van Beveren, L., Roets, G., Buysse, A. and Rutten, K. (2018), "We all reflect, but why?: a systematic review of the purposes of reflection in higher education in social and behavioral sciences", Educational Research Review, Vol. 24, pp. 1-9.

Veine, V., Kalvig Anderson, M., Haugland Andersen, N., Christian Espenes, T., Bredesen Søyland, T., Wallin, P. and Reams, J. (2020), "Reflection as a core student learning activity in higher education - insights from nearly two decades of academic development", International Journal for Academic Development, Vol. 25 No. 2, pp. 147-161, doi: 10.1080/1360144X.2019.1659797.

Walker, P. and Finney, N. (1999), "Skill development and critical thinking in higher education", Teaching in Higher Education, Vol. 4 No. 4, pp. 531-547, doi: 10.1080/1356251990040409.

Walker, A. and Leary, H. (2009), "A problem based learning meta analysis: differences across problem types, implementation types, disciplines, and assessment levels", Interdisciplinary Journal of Problem-Based Learning, Vol. 3 No. 1, p. 6.

Wiggins, G. (1990), "The case for authentic assessment", Practical Assessment, Research, and Evaluation, Vol. 2, p. 2, doi: 10.7275/ffb1-mm19.

Yap, C. (2012), "Bridging the theory-practice gap: work-based business learning", International Journal for Learning, Vol. 18 No. 8, pp. 127-140.

Yorke, M. (2016), “The development and initial use of a survey of student 'belongingness', engagement and self-confidence in UK higher education", Assessment and Evaluation in Higher Education, Vol. 41 No. 1, pp. 154-166, doi: 10.1080/02602938.2014.990415.

\section{Corresponding author}

Elizabeth Miller can be contacted at: Elizabeth.miller@pearsoncollege.com

Employability skills in higher education 